Review

\title{
The need to strategically manage CSP fleet development and water resources: A structured review and way forward
}

\author{
D. Frank Duvenhage ${ }^{\mathrm{a}, ~ *}$, Alan C. Brent ${ }^{\mathrm{a}, \mathrm{b}}$, William H.L. Stafford ${ }^{\mathrm{a}, \mathrm{c}}$ \\ a Engineering Management and Sustainable Systems, Department of Industrial Engineering, The Solar Thermal Energy Research Group, The Centre for \\ Renewable and Sustainable Energy Studies, Stellenbosch University, South Africa \\ b Sustainable Energy Systems, Engineering and Computer Science, Victoria University of Wellington, New Zealand \\ c Green Economy Solutions, Natural Resources and the Environment, Council for Scientific and Industrial Research, Stellenbosch, South Africa
}

\section{A R T I C L E I N F O}

\section{Article history:}

Received 10 April 2018

Received in revised form 30 July 2018

Accepted 8 August 2018

Available online 13 August 2018

\section{Keywords:}

Energy-water nexus

Concentrating solar power

Integrated water resource management

Sustainable development

Renewable energy

Water stress

\begin{abstract}
A B S T R A C T
The rapid global growth in the use of renewable energy to reduce GHG emissions and mitigate climate change, through the inclusion of large amounts of PV and wind in existing electricity grids, has highlighted certain challenges. Most critically, their intermittent supply, necessitates flexible dispatchability from other generators in the grid. Currently, few renewable energy technologies offer this dispatchability, with only concentrating solar power (CSP) offering storage. CSP generates electricity from thermal heat, similar to fossil-driven thermal power plants, with the heat-source being inexhaustible concentrated solar irradiance. The thermal process, however, requires cooling, best achieved with a finite resource; water. CSP is ideally suited to areas of high solar irradiation, typically arid and water stressed. The need for water as a source of cooling is often neglected in the planning and development of CSP. This paper identifies water as a constraint to CSP deployment, and explores CSP's potential contribution to generation through the lens of the water-energy nexus. This aids our understanding of how water availability threatens expected CSP production capacity and places natural limits on its sustainable development. For strategic planning of CSP, we therefore propose the inclusion of integrated water resource management in CSP energy infrastructure planning.
\end{abstract}

() 2018 Elsevier Ltd. All rights reserved.

\section{Contents}

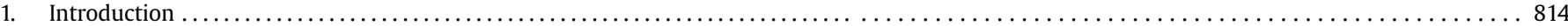

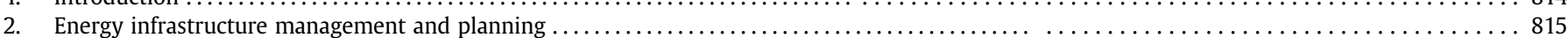

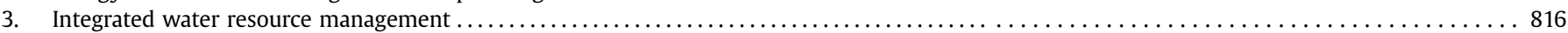

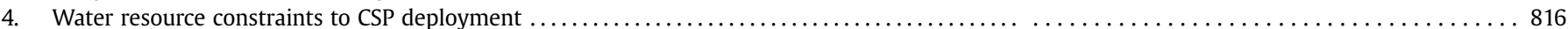

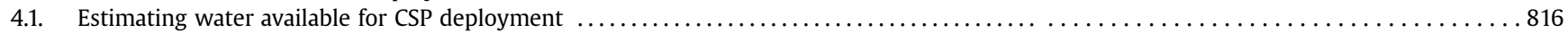

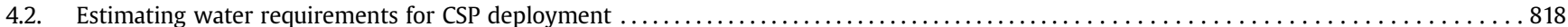

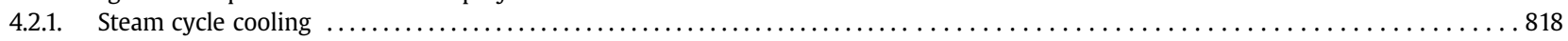

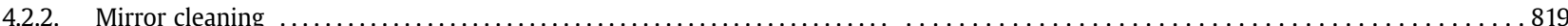

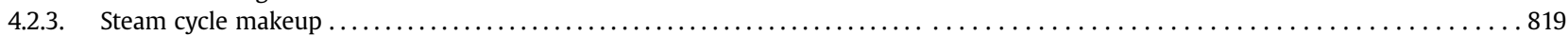

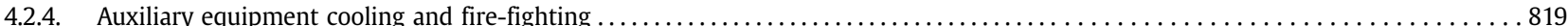

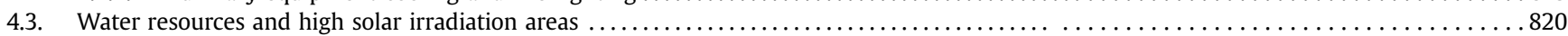

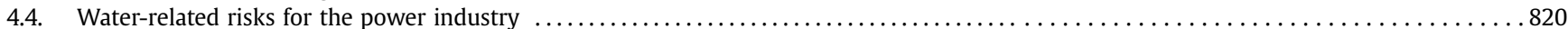

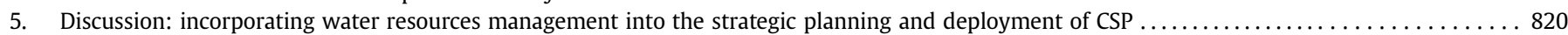

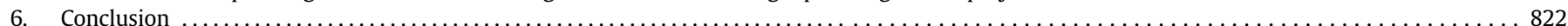

List of acronyms: CSP, Concentrating Solar Power; GIS, Geographic Information Systems; IWRM, Integrated Water Resource Management; PV, Photovoltaic; RET, Renewable Energy Technology.

* Corresponding author.

E-mail address: frankduv@sun.ac.za (D.F. Duvenhage). 


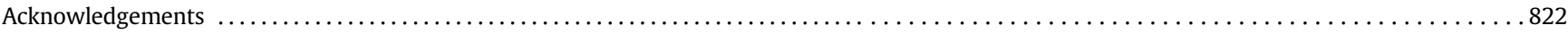

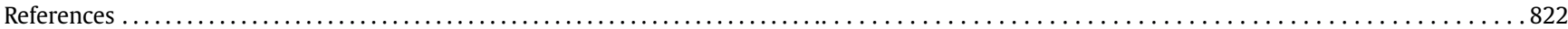

\section{Introduction}

Thermal electricity generation requires water in large quantities; accounting for around $40 \%$ of the national annual water withdrawals in the United States (U.S.) in 2006, and 45\% in 2010 $[1,2]$. Globally, water withdrawals for thermal electricity constituted $15 \%$ of available fresh water resources in 2010 [3]. Due to improved access to technology by lower- and middle-income groups, and the growth in population, it is estimated that electricity demands will double in regions like China, India and Brazil over the next 40 years, and increase sevenfold in Africa by 2050. This population growth and increased consumption patterns will result in greater demands for both water and electricity $[3,4]$. This increase in demand for both resources will take place against a backdrop of greater climate uncertainty, with more people living in areas that are under severe water stress $[5,6]$.

There is a gradual global transition away from conventional electricity generation towards Renewable Energy Technologies (RETs). Solar photovoltaic (PV) and onshore wind turbines have seen the greatest increase in adoption, and are expected to reach $48 \%$ and wind $35 \%$ (82\% combined) of new renewable installed capacity by $2022[7,8]$. The costs of these technologies have decreased greatly from their inception in the late 1980's and early 1990 's, with the technology-specific costs of PV and onshore wind having decreased by $70 \%$ and $50 \%$ since 2010 , respectively $[7,9]$. These technologies, however, experience a major limitation due to resource intermittency [10], and the capacity factors of PV (25\%) and wind (33\%), are much lower than coal or nuclear [11]. Therefore, as the proportion of PV and wind in the power supply mix increases, there is a growing need for storage or more dispatchable supply of electricity in order to meet peaking demands and decreased grid stability [12-14]. Dispatchable renewable energy options include the use of PV and wind with storage in batteries (currently still considered a more expensive solution [15]), powerto-gas, ${ }^{1}$ hydro-pumped storage, bioenergy, and CSP with thermal storage [16]. However, to date gas turbines using natural fossil fuel has been the favoured dispatchable power generation option, because of flexibility, low capital costs and short lead times [17,18].

CSP is a renewable energy technology that generates electricity similarly to other fossil-driven thermal power plants. Its source of heat, concentrated solar irradiance, makes it completely independent from fossil fuels. The addition of heat storage to CSP offers dispatchable electricity by enabling power generation at night and times when there is little or no solar irradiation [19-25]. In this study, the term CSP refers only to either parabolic trough or central receiver technologies with varying amounts of storage. Combined with an international push for carbon emissions reduction from the electricity sector, the global demand for dispatchable renewable energy, in the form of CSP, is likely to increase in regions with high solar irradiation, such as Southern Africa, Australia, and the MENA ${ }^{2}$ region [7]. As the development of CSP increases in countries with favourable solar resources, "solar parks" will emerge, where CSP

\footnotetext{
1 This is especially an option in European countries where heating is an important energy driver, and where supply from renewables like wind regularly exceed demand [16].

2 Middle East and North Africa.
}

and PV plants are grouped together in large quantities to exploit as much high-quality solar resources as possible. Examples of such solar parks can already be found in Morocco and the UAE [26,27]. In South Africa alone, as part of the ministerial determinations on Renewable Energy, a solar park of $5 \mathrm{GW}$ has been planned in the arid Northern Cape Province [28,29].

Similar to all thermal power generation technology, such as conventional fossil fuel power-plants, CSP requires a heat sink and therefore, some form of cooling technology. The most cost-effective and efficient cooling technology is of the "wet-cooling" group, where water is actively used to cool and condense the steam after it has passed through the last steam turbine [30]. An alternative option that is more costly, but uses $90 \%$ less water, is "dry-cooling", which uses ambient air to cool and condense the steam [31]. Its efficiency, therefore, depends on the temperature and humidity of the air [30]. The higher capital cost, combined with its inherently lower efficiency, results in a double cost-penalty for CSP with "dry cooling", compared to "wet cooling". At CSP plants, $90 \%$ of water is typically used for cooling, while the rest is predominately used for cleaning of the solar-field and steam-cycle make-up [32]. Alternative water sources like seawater, and the combined generation of desalinated water and renewable electricity, are technically viable options and have received much attention, but typically require even more piping and pumping infrastructure, adding extra cost $[33,34]$. Combined CSP and desalination are also best-suited in close proximity to coastal areas which unfortunately suffer from lower solar DNI due to higher cloud cover and air-moisture [35]. Many studies have assessed various countries' land potential for CSP based on certain suitability criteria. A summary of the criteria used in literature is given in Table 1.

However, despite the fact that both water and solar resource availability varies spatially and temporally, and the growing evidence of the important linkages between water and energy planning [4,51-65], water resource availability is often poorly considered in CSP planning and deployment [66]. With CSP being a viable solution as a large-scale, fully dispatchable RET, able to counter the intermittency issues associated with higher percentages of PV and wind in countries' energy mixes, its adoption rates are likely to rise. Due to the reliance on high solar irradiation, regions between $15^{\circ}$ and $40^{\circ}$ North and South of the equator, which are typically arid, will experience the most CSP development [67]. With this in mind, it is foreseeable that this increase in CSP adoption in such arid regions might place further pressure on already stressed water resources, and that constraints on water availability may curtail CSP performance and pose risks to the stranding of CSP assets. This is particularly true if CSP planning does not carefully consider water consumption and water availability at a local level. While there have been many studies on the reduction of CSP technology costs [68-74], cost escalations due to loss of production from reduced water availability poses a tangible risk that can be mitigated through appropriate planning. Therefore, there is a need to assess the potential of CSP in areas of high solar irradiation in light of the constraints imposed by water availability, and strategically manage CSP deployment so that it does not increase water scarcity.

This paper aims to provide an approach to the strategic management and planning of CSP infrastructure through the lens of the water-energy nexus. We assess the constraints of water availability 
Table 1

Suitability criteria for CSP plants from literature.

\begin{tabular}{|c|c|c|c|c|c|c|c|c|c|c|c|c|c|c|c|}
\hline Criteria & {$[36]$} & [37] & [38] & [39] & {$[40]$} & [41] & [42] & [43] & {$[44]$} & [45] & {$[46]$} & [47] & [48] & [49] & {$[50]$} \\
\hline Min DNI (MWh/m2/y) & 2 & 2 & 1.8 & 2.2 & 1.7 & 1.8 & 1.8 & 2.6 & 1.5 & 2 & 1.5 & 2 & 1.8 & 1.8 & NA \\
\hline Max Slope (\%) & 2.1 & $1-4$ & 3 & 2 & 3 & $0-3$ & 2 & 1 & $1-5$ & 4 & $2^{g}$ & 2.1 & 3 & 2.1 & 2 \\
\hline \multicolumn{16}{|c|}{ Excluded areas, buffer $(\mathrm{km})$} \\
\hline Wetlands & NA & 0.5 & NA & 0 & $0^{\mathrm{a}}$ & NA & NA & NA & $N A^{d}$ & 0 & NA & 0 & NA & 0 & 0 \\
\hline Lakes & NA & 0.5 & NA & 0 & $0^{\mathrm{a}}$ & NA & 0 & 0 & NA & 0 & NA & 0 & NA & 0 & 0 \\
\hline Rivers & NA & 0.5 & NA & 0.5 & $0^{\mathrm{a}}$ & NA & 0.5 & 0 & NA & 0 & NA & 0 & NA & 0 & 0 \\
\hline Sandy soil & NA & 0.5 & NA & 10 & 0 & NA & NA & NA & NA & NA & NA & NA & NA & NA & NA \\
\hline Forests & NA & 1 & NA & 0 & 0 & NA & 0 & NA & NA & NA & NA & NA & NA & 0 & 0 \\
\hline Protected areas & NA & 1 & NA & 0 & $0^{\mathrm{b}}$ & NA & 0 & $0^{c}$ & NA & $0^{\mathrm{e}}$ & 0 & $0^{e}$ & NA & 0 & NA \\
\hline Agriculture & NA & 2 & NA & 0 & $0^{\mathrm{b}}$ & NA & NA & NA & NA & NA & $35 \%^{\mathrm{h}}$ & NA & NA & 0 & 0 \\
\hline Roads & NA & 2.5 & NA & 0.05 & NA & NA & 0.5 & NA & NA & NA & NA & NA & NA & NA & NA \\
\hline Railways & NA & NA & NA & NA & NA & NA & 0.5 & NA & NA & NA & NA & NA & NA & NA & NA \\
\hline Mines & NA & NA & NA & 3 & NA & NA & NA & NA & NA & NA & NA & NA & NA & NA & NA \\
\hline Populated areas & NA & 0 & NA & 0 & 0 & NA & 0 & 0 & NA & NA & NA & 0 & NA & $6-8$ & 0 \\
\hline High Wind Areas** & NA & NA & NA & NA & NA & NA & NA & NA & NA & NA & NA & 0 & NA & NA & NA \\
\hline Min area $(\mathrm{km} 2)$ & NA & NA & NA & NA & NA & NA & NA & 2 & NA & NA & 4 & NA & NA & NA & NA \\
\hline \multicolumn{16}{|l|}{ Maxi distance to $(\mathrm{km})$} \\
\hline Grid & NA & NA & NA & NA & NA & NA & NA & 20 & $20-100$ & $N A^{f}$ & NA & $30^{i}$ & 40 & $50^{i}$ & $N A^{j}$ \\
\hline Roads/Rail & NA & NA & NA & NA & NA & NA & NA & NA & NA & NA & NA & NA & 40 & $20^{i}$ & $N A^{j}$ \\
\hline Dams & NA & NA & NA & NA & NA & NA & NA & NA & NA & NA & NA & NA & NA & $9^{i}$ & $N A^{j}$ \\
\hline Rivers & NA & NA & NA & NA & NA & NA & NA & NA & NA & NA & NA & NA & NA & NA & $N A^{j}$ \\
\hline
\end{tabular}

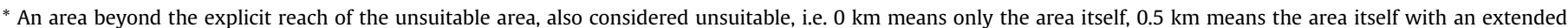
perimeter of $0.5 \mathrm{~km}$ around it.

** Areas identified to pose potential risks to CSP structures.

a The use of buffers is mentioned but no detail on their extent is given

b The study considered three different scenarios: one excluding, one including protected areas, and one including agricultural areas.

c The study used vegetation maps categorized as "critically endangered", "endangered", "vulnerable" and "least threatened", excluding all categories but "least threatened".

d The study limited all areas remaining after applying the other suitability criteria to only $1 \%$ of the identified area, in order to allow for reduced availability due to other exclusion considerations.

e "Environmentally sensitive lands" and Aboriginal Heritage sites are excluded.

${ }^{\mathrm{f}}$ While the benefit of closer proximity to transmission infrastructure is discussed, it is not used as a limiting factor.

g Slopes up to $7 \%$ are considered along with restrictions on the orientation of the slope (North or South), but only $<2 \%$ is considered explicitly suitable.

h Percentage of land cover type considered for CSP development. Similar percentages are applied to other land cover types.

i The study used a weighted approach to identify more and less suitable areas according to stakeholder inputs; thus, areas closer to the grid are considered more suitable, an those further are less.

$\mathrm{j}$ The study modelled the costs associated with building the required infrastructure according to the distance from the infrastructure.

on CSP deployment and propose an approach to the sustainable management and planning of CSP infrastructure. The methodology used in this paper is that of a narrative literature review in order to present a broad perspective of this subject, describe the problem, its context, and opportunities for management $[75,76]$. The need for improved management and planning of CSP infrastructure in light of the water constraints point to the physical asset management of CSP being integrated with water resource management [77-79].

\section{Energy infrastructure management and planning}

The physical asset management of CSP involves the integration of CSP generation with the national power generation mix and requires a process of integrated energy infrastructure management. It becomes increasingly challenging to integrate and coordinate energy infrastructure management and planning when the electricity supply market is liberalized or partially deregulated and independent power producers are allowed to enter the regulated market and supply electricity to the national grid [80]. The challenge is to integrate and plan the developments so that supply can be optimised with demand. In South Africa, energy mix expansion is regulated by policy and the future generation mix options are determined by national plans such as the Integrated Resource Plan, Integrated Energy Plan, National Infrastructure Plan and departmental strategic plans [81-84].

Infrastructure asset management is defined in the globally recognised International Infrastructure Management Manual, as "a systematic approach to the procurement, maintenance, operation, rehabilitation and disposal of one or more assets, integrating the utilization of assets and their performance with the business requirements of asset owners or users, with the main focus being the continuous alignment of asset performance to meet service delivery outputs to deliver the desired outcomes" [85]. It considers all phases of infrastructure projects and how they are to be managed in order to continuously ensure optimum performance and costeffectiveness. When considering the planning phase of electricity infrastructure, there are three categories; strategic, tactical and operative planning [80]. Strategic planning focuses on long-term decisions like investment planning, tactical plans are mediumterm ones that focus on, amongst others, project management and budgeting activities, and operational planning looks at shortterm tasks like grid stability and plant operation. This paper focusses on strategic infrastructure planning, since the investmentintensive expansion of CSP fleets is under consideration.

Strategic energy infrastructure planning determines the longterm investment timelines for new power plants, and the decommissioning of old ones, in order to maintain a desired power generation and specific mix of technologies in the electricity power supply $[85,86]$. These studies make use of multi-criteria modelling packages, such as PLEXOS, in order to determine the optimal mix of power generation options-based on their technical and practical capabilities, cost of capital, operation and maintenance costs, and future forecasted electricity demand [87]. However, this type of planning does not provide detailed insight into spatial planning or resource distribution, particularly in the case of RETs [23]. The challenge with RETs is that their operation is highly variable spatially, necessitating more detailed approaches to strategic 
energy infrastructure planning. Furthermore, these plans do not always carefully consider the water availability for electrical power generation, although a few studies have assessed the amount of water that will be needed to accommodate various power generation mixes with different associated cooling technologies [88-90]. It is argued that this combined total water consumption of energy mixes can be minimized through appropriate technology (power and cooling) selection during the strategic planning phase of energy infrastructure [91].

In the case of South Africa, the Integrated Resource Plan contains the details and schedules for the addition of particular capacities and power generation technologies to the grid, and responds to the White Paper on Energy Policy (1998), and White Paper on Renewable Energy (2003) that highlights the need for affordable renewables in the energy supply mix [92-94]. The Integrated Resource Plan informs the targets of the Renewable Energy Independent Power Producer Procurement Program and results in a competitive bidding process by independent power producers $[95,96]$. This has resulted in the allocation of $6428 \mathrm{MW}$ of RET capacity between 2010 and 2015 through five rounds of bidding, of which $2372 \mathrm{MW}$ are PV, $3367 \mathrm{MW}$ are Wind and $600 \mathrm{MW}$ are CSP, with the rest being small hydro, landfill gas, biomass and biogas projects [97,98]. The National Energy Regulator of South Africa (NERSA) has also assisted independent power producers to sell electricity through enabling grid access and the partial liberalisation of power supply markets. The Integrated Resource Plan is used by the Department of Energy of South Africa (DoESA) to place targets and timelines for installed capacities of different technologies, thereby serving as the long-term strategic energy mix expansion plan [99].

There are various CSP modelling software packages available and these have been reviewed previously [100]. The particular models that can be used to assess plant output, water consumption and economics include: DELSOL, SAM, SOLENERGY, EXCELERGY, TRNSYS and ColSimCSP, of which the System Advisor Model (SAM) is most notable in academic literature [100,101]. ColSimCSP was recently specifically adapted to simulate CSP operation and water consumption for the international MinWaterCSP project by the European Union [102,103].

\section{Integrated water resource management}

Integrated Water Resource Management (IWRM) is a process that promotes the coordinated development and management of water, land and related resources, in order to maximize the resultant economic and social welfare in an equitable manner without compromising the sustainability of vital ecosystems [104]. It is the response from practitioners and academics within the natural resource management industry to what has since been identified as a lacking approach to rapidly changing natural systems [105]. IWRM acknowledges that water resources within catchments or river basins are complex, and that their interaction with equally (if not more) complex socio-economic and ecological systems add another level of complexity to their interactions [106,107].

In a detailed bibliometric analysis of research trends in the water resource sector, Zare et al. (2017) found that since the 1980s, when there were less than a total of 50 publications per year in the broad field of "Integrated water assessment and modelling", this has increased to in excess of 1100 per year in the 2010s [108]. Furthermore, the analysis found that the word most prevalent in titles, keyword lists and abstracts was "management", alluding to the growing realisation of the importance of the concept of active involvement and planning in how human activities interact with water resources. A sharp increase in research focussed on IWRM is seen from 1992 and this is likely due to the publication and formalization of the United Nations (UN) Agenda 21, chapter 18, which emphasises the importance of all UN member states in establishing sound IWRM practices [109], and provides definitions on what constitutes IWRM and guidelines on how to establish such strategies [110]. It suggests that IWRM should be carried out at the catchment or sub-catchment level in the pursuit of the following four cardinal principles:

- IWRM strategies should be dynamic, collaborative, iterative and cross-sectoral with a special focus on identifying and protecting potential freshwater supply sources, and which considers not only environmental and human health wellbeing, but also technological means and socio-economic goals;

- Planning for sustainable and balanced use, and conservation and management of water resources should be based on local community needs within the agenda of national economic development policies;

- IWRM must include the design, implementation and reassessment phases of on-going projects and programmes to ensure they remain both economical and socially relevant through full, indiscriminate public participation;

- The identification and improvement of appropriate institutional, legal and financial instruments that ensure that water policies and their execution positively contribute to sustainable social progress and economic growth.

Following the above principles as well guidelines from other NGOs and development agencies, the Water Environment Research Foundation (U.S.) proposed a framework for Sustainable Water Resource Management [111]. This framework makes the distinction between "integrated" and "sustainable" water resources management, based on the concept that sustainable use of water resources should be a natural outcome of IWRM as much as it is set as a goal. In lieu of this, they developed the process flow-chart, shown in Fig. 1, to guide entities responsible for water resources management and related decisions. The framework consists of parallel proactive- and crisis-components of water resources management, and is adaptable to any water-related management problem. Step 1, the realisation that a water crisis has emerged, is omitted in this representation of the process flow diagram since the steps that need to be taken prior to this, and in response, are of interest. It is important to note that the principles of Steps 2 to 9 of the crisis management process are encapsulated in Steps 10 to 20 of the proactive management process, which highlights the need for strategic planning.

The Sustainable Water Resource Management framework also highlights the need for participation and inclusion in considering the management and allocation of water resources so that water resources management is tailored to local needs. This consultation and inclusivity must be considered at different levels, with consideration of local communities, but within the regional (or national) context and policy perspective [112].

\section{Water resource constraints to CSP deployment}

In order to explore the constraints posed to CSP deployment, the details regarding water consumption at CSP plants and water resource availability in countries of high solar irradiation need to be examined in some detail.

\subsection{Estimating water available for CSP deployment}

Estimating water availability for industrial water use, particularly for CSP, needs to consider both the water quantity and quality [113]. Both can be modelled according to complex runoff models 


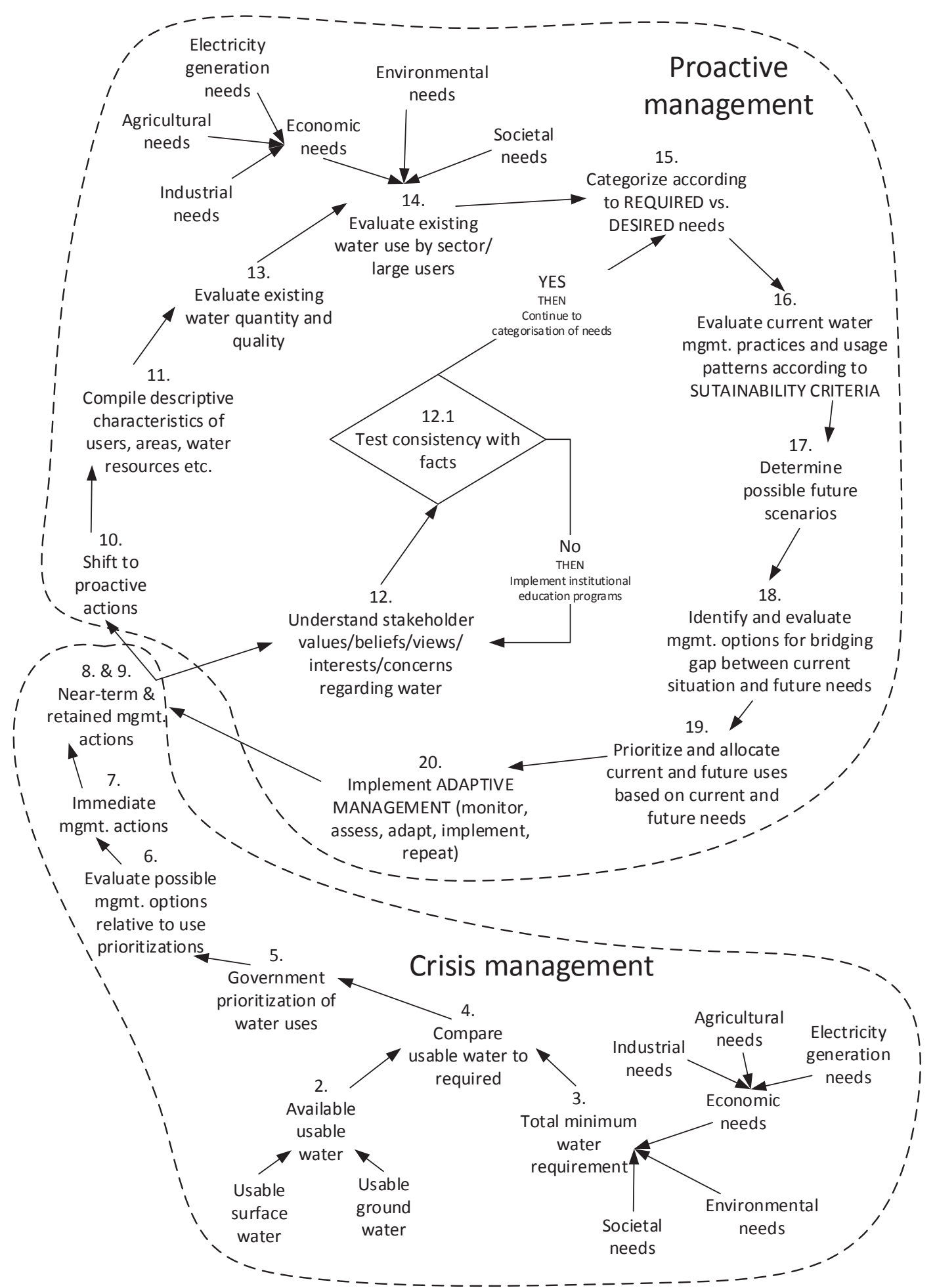

Fig. 1. Sustainable Water Resource Management framework process flow-chart. Recreated from Ref. [111].

that attempt to accurately approximate the hydrological cycle from a sub-catchment to a national and in some instance global scale [114-116]. These intricate computer models consider a range of input variables on water quantity and quality, and approximate water resource availability using clearly defined parameters for surface water and aquifer balances, an overview of typical inputs and outputs is shown in Table 2 [117-119].
These models use existing rainfall and hydrological data to model stream flows and storage capacities, and can also carry out scenarios analysis to understand various system interdependencies; such as ground water salinity and the impact of agricultural and mining activities on local water resource quality $[120,121]$. These water resource modelling packages typically take the form of system network models [117]. They are comprised of 
Table 2

Overview of runoff water model input variables and outputs.

\begin{tabular}{|c|c|}
\hline Model inputs & Model outputs \\
\hline Topography on runoff quantities and directions. & Potential recharge. \\
\hline The impact of geology on the absorption of water into different ground types and this impact on aquifer recharge rates. & Aquifer recharge. \\
\hline The quantification of evapotranspiration rates for different plant and crop types. & Surface water baseflow. \\
\hline The prevalence of crop types in different areas. & Groundwater baseflow. \\
\hline The withdrawal and consumption rates of various industries and socio-economic activities. & Stream interflow. \\
\hline Evaporation rates. & Transmission losses. \\
\hline Rainfall estimates from detailed weather forecasting models. & Groundwater evapotranspiration. \\
\hline Dam storage capacities and historic levels. & Groundwater outflow and storage. \\
\hline Silt deposit rates in dams. & Rainfall and runoff. \\
\hline
\end{tabular}

various modules describing the underlying factors that interact with water resources; such as irrigation modules, mining modules, demand nodes and consumption nodes [119]. These modules need to be developed in adequate detail to assess water availability in support of water allocation decisions and formulation of water policy [120]. In South Africa, the recent water resources appraisal used measured stream-flow data to calibrate the WRSM2000 hydrological model; in order to more accurately estimate the mean annual runoff and hence surface water availability and its level of assurance, given the current and future demands [122,123].

\subsection{Estimating water requirements for CSP deployment}

In the light of Sustainable Water Resource Management, water requirements take into account social, economic and environmental needs. Minimum water requirements refers to the minimum amount of water required to sustain the most necessary activities under drought conditions; and typically refers to the water required to fulfil basic human-needs and the functioning of critical ecosystems. To estimate the local water availability for CSP deployment, one needs to first ensure available water resources are allocated to the basic human needs reserve and the ecological reserve. Once these needs are met, the water available for CSP deployment can then be considered in the context of various other industrial, domestic and agriculture water demands.

The water withdrawals of CSP plants are similar to that of other thermal power plants, in that the majority of water being used at a plant is for cooling purposes $[124,125]$. Water withdrawals refer to the gross amount of water abstracted from a source, and encompass water that is used and lost from the point of abstraction (non-return flows) as well as water that is used and then returned to the point of abstraction (return flows). Consumptive use refers to water that is extracted from a source, and used in a process or incorporated into a product such that it is so altered that it cannot be returned to the source [2]. In the case of CSP, most use is consumptive, with little to no water being returned to the source because it is evaporated to the atmosphere either as part of the cooling process or in evaporation ponds. The water use of a CSP plant consists of: Steam cycle cooling cycle (recirculating wet cooling, air-cooled condenser), mirror cleaning, steam cycle (boiler feedwater closed cycle), auxiliary equipment cooling cycle, firefighting systems, dust suppression, and potable water for operational personnel.

\subsubsection{Steam cycle cooling}

By far, the largest portion of water used at a CSP plant is steam cycle cooling (in the case of wet-cooling). This is the major concern when it comes to water use at any thermal power plant since the condensing and cooling of the steam exiting the low-pressure turbine is critical to plant efficiency and operation [32]. There are two major methods used for cooling at CSP plants: recirculating (evaporative) wet-cooling and dry-cooling. ${ }^{3}$

Wet-cooling technology uses water as the cooling fluid, absorbing the latent heat of condensation from the steam exiting the lowpressure turbine. There are two types of wet-cooling technologies: (i) Once-through cooling-water is extracted from a source, used to cool the steam in a condenser and returned to the source to replenish the water abstraction, albeit with water at an elevated temperature [126]. (ii) Recirculating, evaporative cooling-cooling water is circulated between a cooling tower and a condenser; but the warm cooling water is evaporated into the atmosphere. These two wet-cooling technologies are depicted in Fig. 2 [127]. Oncethrough cooling has never been used for CSP because of the lack of adequate water resources in high DNI areas. Recirculating wetcooling is, however, very prevalent, with almost $80 \%$ of all operational plants using this cooling technology. ${ }^{4}$ This is due to the lower capital cost of wet-cooling technology and greater efficiency, compared to dry-cooling [32]. Furthermore, compared to recirculating wet-cooling (hereafter referred to as wet-cooling only), the reduced efficiency of dry-cooling results in a larger solar field required to maintain the power output, at higher capital costs [31].

Wet-cooling is very effective because the heat from the steam is rejected to the air through the evaporation of the cooling water. Therefore, compared to dry-cooling, the wet-cooling process is less affected by variations in ambient air temperature, since the evaporative cooling is dependent on wet bulb temperature, and as a result of this, wet cooling uses almost 10 times more water than dry-cooling [31]. There are two major mechanisms of water loss in wet-cooling. Evaporative cooling of the warm water leaving the condenser in the cooling towers, is the primary heat transfer method and water loss mechanism. This results in the concentration of minerals each time water is lost to the atmosphere. Secondly, dilution is required to prevent the cooling water from becoming saturated with minerals; which will result in scale formation and reduced cooling efficiency. Dilution is achieved by adding fresh cooling "makeup water", and rejecting the higher concentration cooling water, known as "blowdown", thereby continuously limiting mineral saturation and its consequences [30].

Dry-cooling uses air for cooling instead of water and requires an air-cooled condenser where the steam passes through a bundle of tubes, and ambient air absorbs the heat. This means that the effective cooling that can be achieved is dependent on the dry-bulb temperature of the air; which is always higher than the wet bulb temperature in dry, arid conditions-where CSP is most prevalent. Further, ambient temperatures are highest on days of high solar irradiation, resulting in the highest efficiency losses on days that are supposed to be the most productive [128]. Dry cooling requires

\footnotetext{
${ }^{3}$ Based on NREL's global projects database available at https://www.nrel.gov/csp/ solarpaces/.

${ }^{4}$ Calculated from NREL's Concentrating Solar Power Projects database at https:// www.nrel.gov/csp/solarpaces/, and excluding unreported cooling technologies.
} 


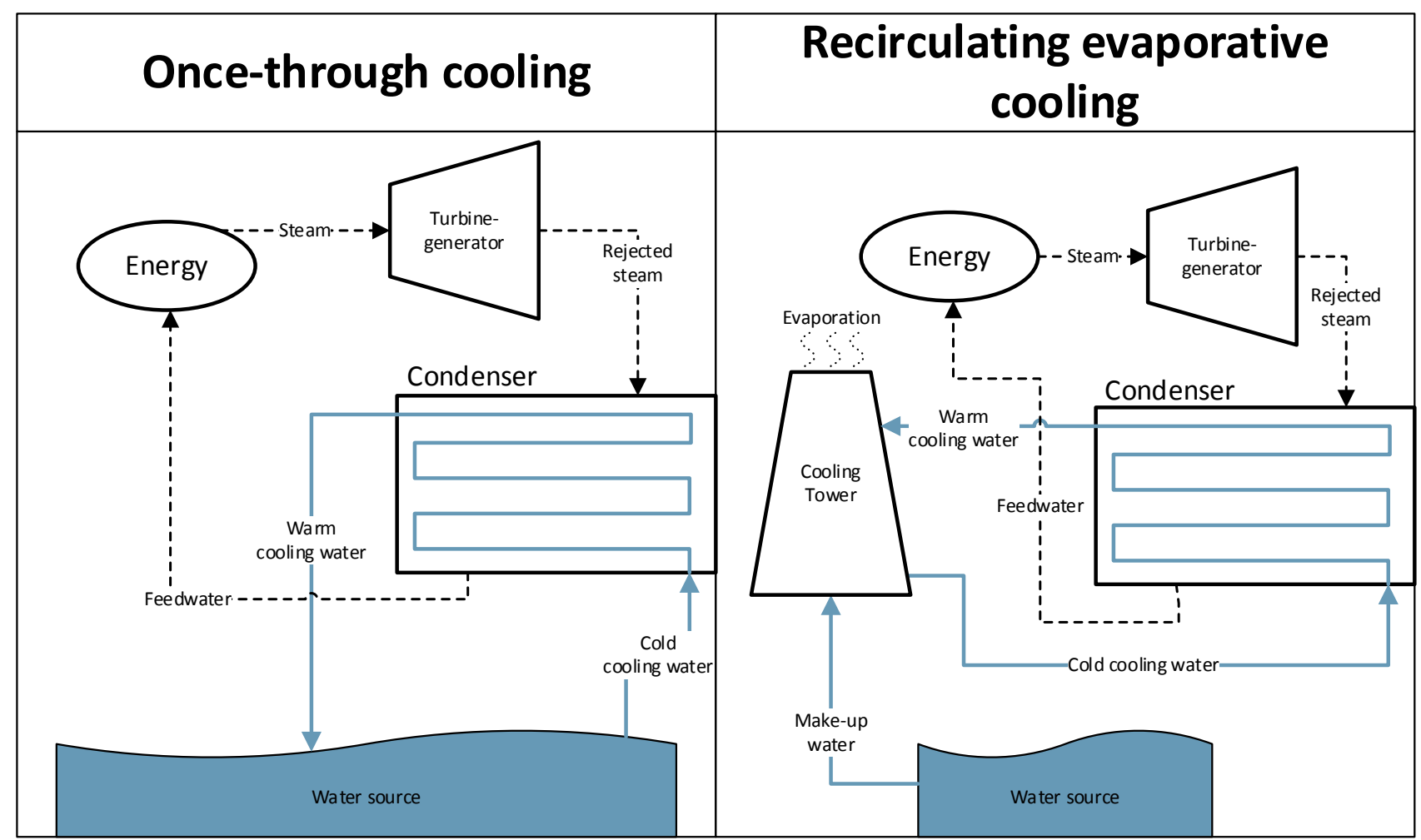

Fig. 2. Schematic comparing once-through and recirculating evaporative cooling. Recreated from Ref. [131].

minimal water only for cleaning of the condenser tube bundles. This cleaning is carried out at fixed intervals to prevent external fouling on the tubes and ensure efficient operation [129]. As discussed, the main drawback of dry-cooling is the reduced CSP power plant efficiency and higher capital costs, and resulting higher cost of electricity. Studies have found that, depending on the location, drycooling can result in increased generation costs of between $5.65 \%$ and $7.87 \%$ for cool and hot climates, respectively [128].

The overall plant water consumption rates of various power technologies have been compared in other studies [130-132] and the specific water use for CSP with wet- or dry-cooling were estimated to be in the following ranges (Fig. 3). Clearly, dry-cooling uses between $91 \%$ and $97 \%$ less water than wet-cooling, (trough and central receiver technology, respectively).

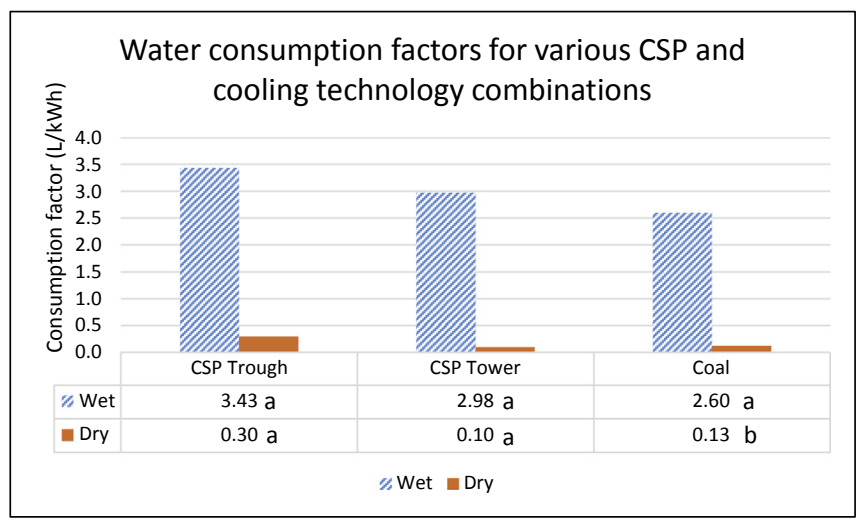

Fig. 3. Comparison of water consumption factors for various CSP and cooling technologies, compared to that of Coal. a - Mean values taken from Ref. [135]. b - Mean value calculated from Ref. [70].

\subsubsection{Mirror cleaning}

Mirror cleaning is the second most significant predictable consumptive use of water at CSP plants. Mirror cleaning is carried out at predetermined intervals using defined amounts of water per square meter of mirrors. Typically, cleaning water is collected, either by the cleaning trucks or the storm water drainage system that conveys possibly contaminated water to the evaporation ponds. Mirror cleaning at trough plants can be between an effective 75-152 L/MWh [133], but typically only accounts for between $1.4 \%$ and $2 \%$ of total CSP water consumption [32,134]. In a study to reduce the amount of water required for cleaning, it was found that at SHAMS 1 parabolic trough plant in Abu-Dhabi, cleaning of the 192 loops twice a week, each requiring $1.5 \mathrm{~m}^{3}$ of demineralized water, and has been reported to amount to between 11 and 31 million litres of water per year [135]. There are opportunities to reduce this water use by between $25 \%$ and $50 \%$, through the recovery and recycling of water [135,136].

\subsubsection{Steam cycle makeup}

Steam cycle makeup water is another consumptive water use at any CSP plant, and is typically between 113 and $228 \mathrm{~L} / \mathrm{MWh}$ [133]. This accounts for around $3 \%$ of total annual water consumption for wet-cooled plants, and between $44 \%$ and $53 \%$ for dry cooled plants [31]. Generally, it is assumed that total steam cycle makeup remains almost constant irrespective of the cooling system employed, except for a slight increase for dry-cooled plants at start-up. This is based on the premise that ACCs take longer to achieve full vacuum and reach optimal steam cycle chemistry, resulting in more steam cycle and quench water being consumed in the process [31].

\subsubsection{Auxiliary equipment cooling and fire-fighting}

Equipment cooling water is circulated between a water-cooling unit (typically a bank of air-cooled condensers) and the 
components that need to be cooled, such as pump lubrication systems and bearings. Fire-fighting equipment is vital to ensure the safe operation of any CSP plant since receiver temperatures are typically between $290^{\circ} \mathrm{C}$ and $390{ }^{\circ} \mathrm{C}$ at trough plants and even higher at central receiver plants-in excess of $500{ }^{\circ} \mathrm{C}$ [32], and synthetic oils are often used as the heat transfer fluid, posing a significant fire-risk [137,138].

\subsection{Water resources and high solar irradiation areas}

Once the available water resources have been estimated, the constraint of water on CSP deployment in areas of high solar irradiation can be assessed. Obviously, areas of high solar irradiation are most suitable for CSP, but are also the most water-scarce, arid regions globally. Fig. 4 clearly shows the agreement between high solar irradiation (DNI exceeding $2000 \mathrm{kWh} / \mathrm{m}^{2} /$ year or $6 \mathrm{kWh} / \mathrm{m}^{2}$ / day) and high aridity (chess-board cross-hashing), and that these are areas where most CSP projects are located.

The maps in Fig. 5 show the intersection of existing CSP locations with a) arid areas; b) water-stressed areas; c) areas with high seasonal resource variability; and d) areas with high inter-annual resource variability. Map a) clearly shows that CSP plants are mostly located in areas considered semi-arid, arid or hyper-arid, according to the United Nations Environment Programme's (UNEP) aridity index. It is based on the UNEP classification and is a measure of precipitation availability over atmospheric water demand [139]. Map b) shows the intersection between CSP locations and areas with medium to extremely high baseline water stress, showing that CSP-suitable areas already experience lower availability as compared to demands [140]. Map c) and d) shows that these areas are sensitive to variability, both seasonally (monthly) and inter-annually, increasing water-related risks.

Higher temperatures are typically associated with areas of high DNI, and as mentioned before, these warmer atmospheric conditions at CSP plant locations further negatively impact cooling efficiency. Higher atmospheric temperatures are associated with higher cooling-water consumption at wet-cooled plants, and likewise greater efficiency losses in the case at dry-cooled ones [31]. As a result this, CSP with wet cooling typically uses greater amounts of water when compared to other conventional power generation plants with similar wet cooling technology [130]. This mismatch between optimal CSP locations and impact on cooling efficiency further adds to the disparity between water resource availability and CSP's consumptive demands in these areas and highlights the need to take local conditions into consideration in CSP deployment.

\subsection{Water-related risks for the power industry}

Water constraints are a significant risk for the power industry, as shown by the recent power-plant curtailments in India. CSP operations had to be curtailed at 18 different power plants, because of reduced water availability; with a loss of $14 \mathrm{TWh}$ of power generation in 2016, and curtailment having gradually increased from 6 TWh in 2013 [141]. The Parli Thermal Power Station in Maharashtra, India, had a capacity factor of only $38 \%$ due to water availability constraints, and this resulted in a loss of revenue in the order of $\$ 1.2$ billion in 2016 [141]. The curtailment at the Farakka plant in West Bengal was due to lower than expected rainfall and an interboundary water management policy requiring water to be allocated to supply Bangladesh [142]. These incidents highlight the financial risks of poor water resource management in strategic energy infrastructure planning. This risk is even more severe for RETs since their generation relies on the availability of a natural resource (solar irradiation or wind, etc.), and therefore cannot be regained once production has been lost. The above incidents highlights that many developed countries suffer from a lack of integrated water resource management in CSP planning and deployment. In the U.S. between 2000 and 2015, there were 43 separate incidents of power plant curtailment due to water availability and temperature issues $[143,144]$. Furthermore, the impact of drought conditions on U.S. power plants highlighted that few regulatory bodies have established detailed priority systems for allocating water use to certain water uses during constrained availability [145].

\section{Discussion: incorporating water resources management into the strategic planning and deployment of CSP}

The suggested approach of this paper is that of combining strategic energy infrastructure planning with integrated water resource management. This integration is essential for the successful deployment of CSP; since the areas of high CSP potential are located in hot and arid areas, where water availability for CSP cooling may be limited and a constraint to CSP reaching its potential for deployment. Strategic planning and policy support is

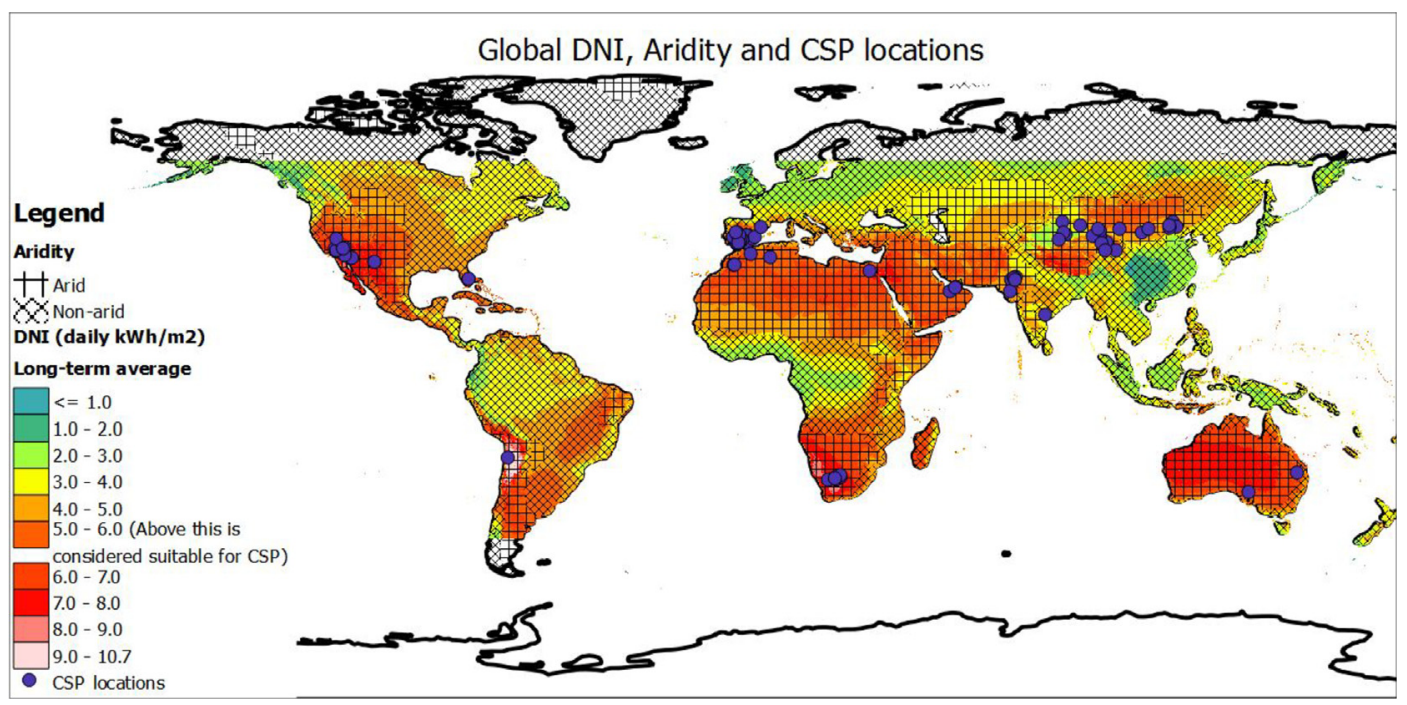

Fig. 4. Global DNI, Aridity and CSP locations. 


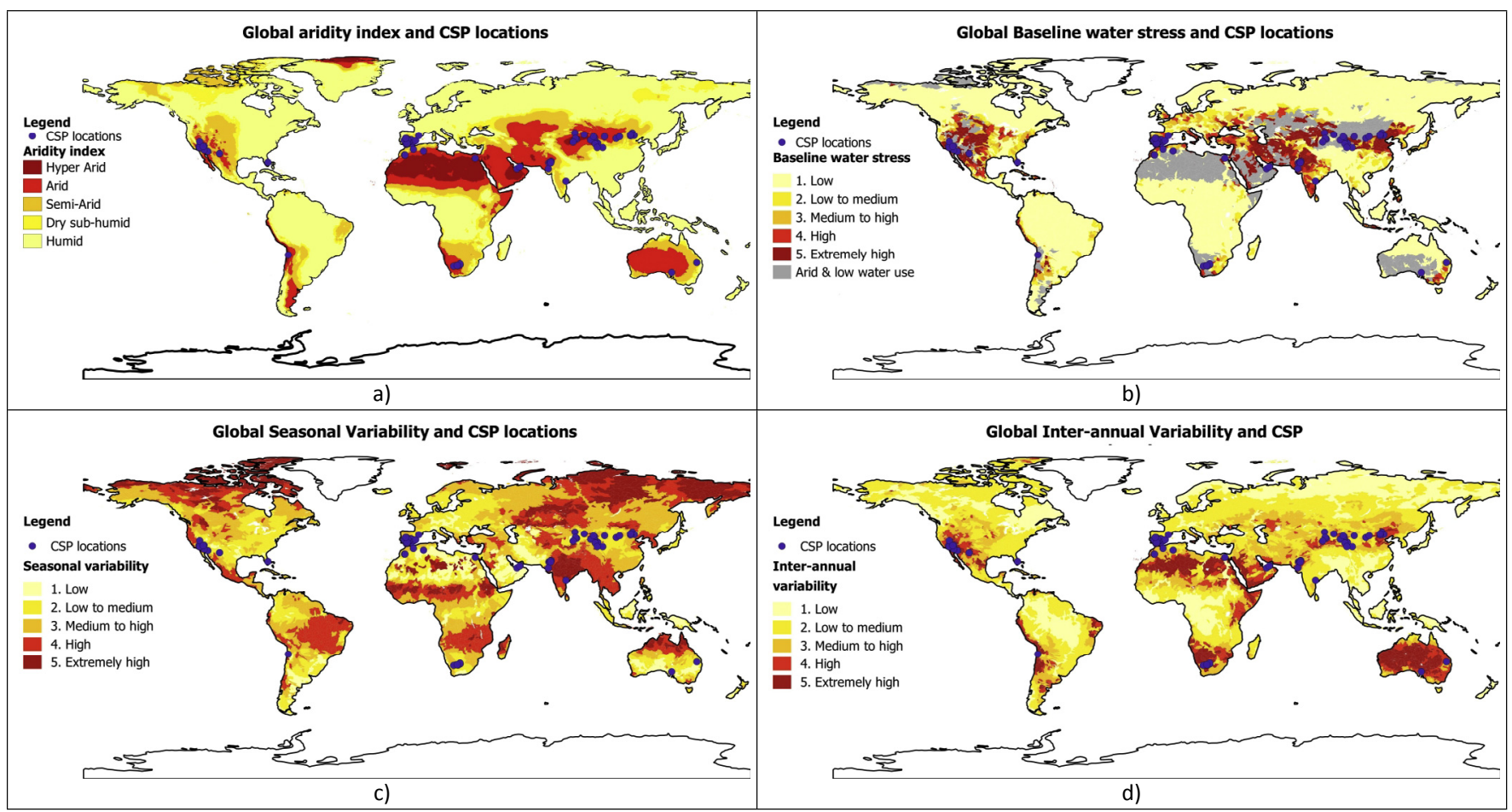

Fig. 5. Maps of planned and existing CSP locations and: a) aridity; b) water stress; c) seasonal resource variability; d) inter-annual resource variability. Maps compiled using aridity data from the UN's Aquastat database (available at http://ref.data.fao.org/map?entryld=221072ae-2090-48a1-be6f-5a88f061431a), water stress data from the World Resources Institute's (WRI) Aqueduct study (available at http://www.wri.org/publication/constructing-decision-relevant-global-water-risk-indicators), Global DNI data from SolrGIS (available at https://solargis.com/maps-and-gis-data/download/world) and NREL's Concentrating Solar Power Projects database (see previous footnotes).

needed to ensure that CSP deployment has minimal impacts on water resources, and that the deployed CSP plants reach their expected performance through the prevention of curtailment due to water availability constraints.

Water is used in different processes within a CSP plant. The water consumption is influenced by the CSP power plant capacity, the cooling technology used, and the solar resource and atmospheric conditions at a particular location. CSP performance at a given locality needs to be modelled in light of seasonal water availability from spatial and temporal variation. The performance of CSP will influence the financial viability or levelised cost of electricity produced. The viability of CSP is also strongly influenced by feed-in tariffs and the market value of dispatachable power. The ability of CSP with storage to produce dispatchable power is an obvious advantage to meet peaking loads, and may receive favourable tariffs to do so. Conversely, the lower night-time tariff may be less favourable due to reduced demand [146]. However, generation during night can reduce CSP water consumption since production during these times will take place under cooler ambient conditions. It is challenging to model CSP deployment potential at a national scale, since various CSP capacities and configurations are possible in each location according to grid expansion requirements, and various possible future feed-in tariff structures. However, the maximum theoretical generation capacity based on the available suitable land and solar resources can be estimated for each quaternary water catchment area and then the water resources availability and assurance of supply in that catchment can be assessed accordingly.

Water resources are spatially and temporally distributed unevenly at a global, continental, regional, national and even subcatchment level. Drought conditions, defined as periods of restricted water availability due to lower than required rainfall, occur at unpredictable multi-year intervals and result in increased competition for water resources among water users [147]. It is therefore important to be able to evaluate a long period of water resource data in order to see the drought occurrence frequency, as well as establish the baseline water availability in each quaternary catchment to assess potential vulnerability to CSP curtailment and increased water stress.

There are various modelling tools available to increase our understanding of how water resources can limit CSP from reaching higher levels of potential deployment. Aside from engineering modelling of CSP plant design and hydrological modelling of water resources, geographic information systems (GIS) are particularly valuable in planning energy infrastructure and managing water resources, specifically in an integrated manner. GIS is widely used in both water resource planning and infrastructure planning as a means to visually depict specific information such as evaporation rates, flood occurrences, electrical grids, and the energy and water demands. This makes GIS an ideal final tool to represent the results from the modelling and data analysis above, and use these visual representations (maps) to not only inform decisions, but also guide policy developments [148].

Once the water consumption and water resource availability are both represented in accurate models, the CSP potential can be assessed, and appropriate design requirements can be specified for further deployment. For example, in South Africa, the driving regulatory authority is the Department of Energy, through its Renewable Energy Independent Power Producer Procurement Program (REI4P). This program stipulates various requirements that need to be met by any prospective RET developer, ranging from specifications on the minimum required local content and social and economic development involvement, to minimum plant rampup rates and ability to supply electricity when demand is higher. These national policies directly impact RET plant location, design decisions, operating strategies and costs [149]. 
Water use needs to be regulated and integrated through policy to ensure that water resources are protected, used, developed, conserved, managed and controlled in such a way as to ensure and promote efficient, sustainable and beneficial water use [150,151]. Coal power plants are highly dependent on water in South Africa, while coal mining also incurs significant impacts to water resources [152]. As a result, guidance notes have been issued to prospective coal independent power producers on water availability for further development in coal-rich areas, recommending various water-use efficiency measures [153]. However, similar recommendations for other RETs such as CSP have not been made. This dependence is also highlighted in the possible impact that loss of water supply from pump stations to these coal power plants could result in loss of generation [154]. Policies can inform and encourage certain power plant configurations to achieve desired water consumption rates and also to promote the use of alternative water sources by power plants [155-157]. Coordinated strategic planning between responsible stakeholders can help ensure that targets set out in joint water-energy policies are achieved [158]. Energy infrastructure management and planning will need to integrate water resource availability with the potential for CSP deployment in high solar irradiation areas. In doing so, several questions should guide and frame CSP developments: To what extent is water resource availability and variability a constraint on CSP deployment? Can this constraint be adequately addressed through technologyspecific strategic planning? What alternative sources of water are available in areas with inadequate natural water supply? How can policies be used to promote the use of such alternative sources in order to ensure sustainable management of natural fresh water source? What measures need to be put in place to incentivise responsible use and monitoring of water use at CSP plants?

\section{Conclusion}

With the increasing deployment of solar PV and wind in the electricity generation mix, more responsive dispatchable, or peaking generation capacity, is needed to respond to the changes in demand. CSP with storage can overcome the supply intermittency experienced by many RETs. However, the spatial potential of CSP based on the solar resource needs to be tempered by taking into consideration local water availability for CSP power plant cooling. Hydrological models can assess the water availability at various locations, and this can be spatially superimposed with the solar irradiation using geospatial tools to determine areas where biophysical constraints water scarcity hinders CSP reaching its full deployment potential. Integrated water resources management and national policies for sustainable development can be used as a process to explore how local water resources should optimally be used (which takes into account a range of water demands), and therefore enables a more realistic assessment of water availability for CSP deployment. It will be critical to establish a standardised approach to assessing this dualistic managerial problem, and apply it in different countries within the context of national planning. There may also be instances where international water relations need to be considered. Therefore, CSP infrastructure management and planning needs to be integrated with water resources management to allow for contextual differences between different countries, regions, and specific locations. The development of a model-based guiding framework and methodology to achieve this will provide the required insight to tailor policy specifically suited for the country or region in question, which is needed to enable the sustainable development of CSP.

\section{Acknowledgements}

The authors would like to acknowledge funding from South Africa's National Research Foundation to support the research. The authors confirm that there are no conflicts of interest in this research and that the research is original work stemming from cooperation between various individuals and institutions.

\section{References}

[1] U.S. Department of Energy, Energy Demands on Water Resources Report to Congress on the Interdependency of Energy and Water, 2006.

[2] M.A. Maupin, J.F. Kenny, S.S. Hutson, J.K. Lovelace, N.L. Barber, K.S. Linsey, Estimated Use of Water in the United States in 2010: U.S. Geological Survey Circular 1405, 2014, https://doi.org/10.3133/cir1405. Reston, Virginia.

[3] International Energy Agency IEA, Chapter 17: water for energy. Is energy becoming a thirstier resource, in: World Energy Outlook 2012, Organization for Economic Cooperation \& Development (OECD), International Energy Agency IEA, Paris France, 2012.

[4] World Energy Council, Water for Energy, 2010. London UK.

[5] WWAP (United Nations World Water Assessment Programme), The United Nations World Water Development Report 2015: Water for a Sustainable World, 2015. Paris.

[6] S. Orr, R. Sánchez-Navarro, G. Schmidt, R. Seiz-Puyuelo, K. Smith, J. Verberne, Assessing Water Risk a Practical Approach for Financial Institutions, WWF Germany, Berlin Germany, 2011.

[7] International Energy Agency, Renewables 2017 Analysis and Forecasts to 2022, 2017. Paris France.

[8] IRENA, The Power to Change: Solar and Wind Cost Reduction Potential to 2025, 2016.

[9] International Energy Agency, World Energy Outlook 2017, 2017. Chapter 1, http://www.iea.org/publications/freepublications/publication/WEB_ WorldEnergyOutlook2015ExecutiveSummaryEnglishFinal.pdf.

[10] M. Milligan, B. Parsons, A comparison and case study of capacity credit algorithms for intermittent generators, in: Proc 1997 Am Sol Energy Soc Annu Conf, 1997, pp. 329-334.

[11] U.S. Energy Information Administration, Electric Power Monthly with Data for October 2015, 2015.

[12] R. Piwko, Intermittency Analysis Project: Appendix B: Impact of Intermittent Generation on Operation of California Power Grid, California Energy Commission, PIER Renewable Energy Technologies Program, 2007. CEC-5002007-081-APB.

[13] U.S, Department of Energy. Staff Report to the Secretary on Electricity Markets and Reliability, 2017, p. 187.

[14] P. Denholm, K. Clark, M. O'Connell, On the Path to SunShot: Emerging Issues and Challenges in Integrating High Levels of Solar into the Electrical Generation and Transmission System, National Renewable Energy Laboratory, Golden, Colorado, 2016, https://doi.org/10.2172/1253978. NREL/TP6A20-65800.

[15] International Energy Agency, World Energy Outlook 2017, International Energy Agency, Paris France, 2017.

[16] M. Götz, J. Lefebvre, F. Mörs, A. McDaniel Koch, F. Graf, S. Bajohr, et al. Renewable Power-to-Gas: a technological and economic review, Renew. Energy 85 (2016) 1371-1390, https://doi.org/10.1016/j.renene.2015.07.066.

[17] J. DiCampli, W. Schulke, Grid Stability: Gas Turbines for Primary Reserve, 2013. V004T09A002.

[18] EPRI, Power Generation Technology Data for Integrated Resource Plan of South Africa: Technical Update, August 2015, EPRI, Palo Alto California, 2015.

[19] R. Sioshansi, P. Denholm, The Value of Concentrating Solar Power and Thermal Energy Storage, NREL, Golden, Colorado, 2010.

[20] S.H. Madaeni, R. Sioshansi, P. Denholm, Capacity Value of Concentrating Solar Power Plants Capacity Value of Concentrating Solar Power Plants, NREL, Golden, Colorado, 2011.

[21] M. Mehos, C. Turchi, J. Jorgenson, P. Denholm, C. Ho, K. Armijo, On the Path to SunShot: Advancing Concentrating Solar Power Technology, Performance, and Dispatchability, National Renewable Energy Laboratory, Golden, Colorado, 2016. NREL/TP-5500-65688.

[22] P. Gauché, S. Pfenninger, A.J. Meyer, T.W. von Backström, A.C. Brent, Modeling dispatchability potential of CSP in South Africa, South Afr. Sol. Energy Conf. 1 (2012) 1-11.

[23] P. Gauché, J. Rudman, M. Mabaso, W.A. Landman, T.W. von Backström, A.C. Brent, System value and progress of CSP, Sol. Energy 152 (2017) 106-139, https://doi.org/10.1016/j.solener.2017.03.072.

[24] T. Telsnig, L. Eltrop, W. Hartmut, U. Fahl, Efficiency and costs of different concentrated solar power plant configurations for sites in Gauteng and the Northern Cape, South Africa, J. Energy South Afr. 24 (2013) 77-89.

[25] P. Gauché, Backström TW. Von, A.C. Brent, A concentrating solar power value proposition for South Africa, J. Energy South Afr. 24 (2013) 67-76.

[26] Z. Jokadar, C. Ponte, in: Ouarzazate Solar Power Complex, Phase 1 Morocco Specific Environmental and Social Impact Assessment, vol. 1, Masen, Rabat, Morocco, 2013.

[27] Dubai Electricity and Water Authority, Facts about the Solar Park, 2017. 
https://www.dewa.gov.ae/en/customer/innovation/renewable-energy/factsabout-the-solar-park. (Accessed 14 February 2018).

[28] J.K. Musango, B. Amigun, A.C. Brent, Sustainable electricity generation technologies in South Africa: initiatives, challenges and policy implications, Energy Environ. Res. 1 (2011) 124-138.

[29] Department of Energy, South African Solar Park Indicative Master Plan, Fluor Corporation, Department of Energy South Africa, 2011. A4PG-RPT-001.

[30] M.J. Rutberg, Modeling water Use at Thermoelectric power plants, Masters Thesis, Massachusetts Institute of Technology, 2012.

[31] C. Turchi, M. Wagner, C. Kutscher, Water Use in Parabolic Trough Power Plants: Summary Results from WorleyParsons' Analyses, NREL, Golden, Colorado, 2010.

[32] U.S. Department of Energy, Concentrating Solar Power Commercial Application Study: Reducing Water Consumption of Concentrating Solar Power Electricity Generation, 2009. Report to Congress.

[33] J.E. Hoffmann, E.P. Dall, Integrating desalination with concentrating solar thermal power: a Namibian case study, Renew. Energy 115 (2018) 423-432, https://doi.org/10.1016/j.renene.2017.08.060.

[34] P. Palenzuela, G. Zaragoza, D.C. Alarcón-Padilla, J. Blanco, Evaluation of cooling technologies of concentrated solar power plants and their combination with desalination in the Mediterranean area, Appl. Therm. Eng. 50 (2013) 1514-1521, https://doi.org/10.1016/j.applthermaleng.2011.11.005.

[35] A. Pugsley, A. Zacharopoulos, J.D. Mondol, M. Smyth, Global applicability of solar desalination, Renew. Energy 88 (2016) 200-219, https://doi.org/ 10.1016/j.renene.2015.11.017.

[36] R. Mahtta, P.K. Joshi, A.K. Jindal, Solar power potential mapping in India using remote sensing inputs and environmental parameters, Renew. Energy 71 (2014) 255-262, https://doi.org/10.1016/j.renene.2014.05.037.

[37] J.N. Gathu, P.A. Odera, E.H. Waithaka, Determination of suitable sites for establishment of large-scale concentrated solar power plants in Kenya, Nat. Resour. 08 (2017) 1-23, https://doi.org/10.4236/nr.2017.81001.

[38] K. Kaygusuz, Prospect of concentrating solar power in Turkey: the sustainable future, Renew. Sustain. Energy Rev. 15 (2011) 808-814, https://doi.org/ 10.1016/j.rser.2010.09.042.

[39] Y Le Fol, K. Ndhlukula, Potential and future of concentrating solar power in Namibia, J. Energy South Afr. 24 (2013) 90-98.

[40] K. Ummel, Concentrating Solar Power in China and India: a Spatial Analysis of Technical Potential and the Cost of Deployment, 2010.

[41] T.V. Ramachandra, R. Jain, G. Krishnadas, Hotspots of solar potential in India, Renew. Sustain. Energy Rev. 15 (2011) 3178-3186, https://doi.org/10.1016/ j.rser.2011.04.007.

[42] A.A. Merrouni, A.B. Mezrhab, A. Mezrhab, CSP sites suitability analysis in the eastern region of Morocco, Energy Procedia 49 (2013) 2270-2279, https:/ doi.org/10.1016/j.egypro.2014.03.240.

[43] T.P. Fluri, The potential of concentrating solar power in South Africa, Energy Pol. 37 (2009) 5075-5080, https://doi.org/10.1016/j.enpol.2009.07.017.

[44] E.W. Ramdé, Site ranking and potential assessment for concentrating solar power in West Africa, Nat. Resour. 04 (2013) 146-153, https://doi.org/ 10.4236/nr.2013.41A019.

[45] J. Clifton, B.J. Boruff, Assessing the potential for concentrated solar power development in rural Australia, Energy Pol. 38 (2010) 5272-5280, https:// doi.org/10.1016/j.enpol.2010.05.036.

[46] J. Dominguez Bravo, X. Garcia Casals, I. Pinedo Pascua, GIS approach to the definition of capacity and generation ceilings of renewable energy technologies, Energy Pol. 35 (2007) 4879-4892, https://doi.org/10.1016/ j.enpol.2007.04.025.

[47] L. Dawson, P. Schlyter, Less is more: strategic scale site suitability for concentrated solar thermal power in Western Australia, Energy Pol. 47 (2012) 91-101, https://doi.org/10.1016/j.enpol.2012.04.025.

[48] D. Dahle, D. Elliott, D. Heimiller, M. Mehos, R. Robichaud, M. Schwartz, et al., Assessing the Potential for Renewable Energy Development on DOE Legacy Management Lands, DOE/GO-102008-102435, NREL, Golden, Colorado, 2008.

[49] A. Aly, S.S. Jensen, A.B. Pedersen, Solar power potential of Tanzania: identifying CSP and PV hot spots through a GIS multicriteria decision making analysis, Renew. Energy 113 (2017) 159-175, https://doi.org/10.1016 j.renene.2017.05.077.

[50] H. Broesamle, H. Mannstein, C. Schillings, F. Trieb, Assessment of solar electricity potentials in North Africa based on satellite data and a geographic information system, Sol. Energy 70 (2001) 1-12, https://doi.org/10.1016/ S0038-092X(00)00126-2.

[51] J. MacKnick, R. Newmark, C. Turchi, Water Consumption Impacts of Renewable Technologies: the Case of CSP, U.S. Department of Energy, Baltimore, MD, 2011. AWRA 2011 SPRING Spec. Conf.

[52] P. Kotzé, Water and energy: How much water will we need to keep the lights on? Water Wheel 14 (2015) 22-25.

[53] M. Govender, S. Leyde, T. Fischer, M. Weston, Strategic Assessment and Mapping of Opportunities for Water Desalination and Water- Use Optimisation of Concentrated Solar Power, Report No.2382/1/16, Water Research Commission, Pretoria, 2016.

[54] D.J. Rodriguez, A. Delgado, P. Delaquil, A. Sohns, Thirsty Energy, 2013. Washington DC.

[55] IRENA, Renewable Energy in the Water, Energy \& Food Nexus, 2015.

[56] International Energy Agency, Water Energy Nexus - World Energy Outlook 2016 Excerpt, IEA, Paris France, 2016, https://doi.org/10.1021/es903811p.
[57] World Bank Group, Modeling the Water-energy Nexus: How Do Water Constraints Affect Energy Planning in South Africa? World Bank Group, Washington DC, 2017.

[58] US DOE, The Water-energy Nexus: Challenges and Opportunities, DOE, US, 2014.

[59] M.R. Nogueira Vilanova, J.A. Perrella Balestieri, Exploring the water-energy nexus in Brazil: the electricity use forwater supply, Energy 85 (2015) 415-432, https://doi.org/10.1016/j.energy.2015.03.083.

[60] X.D. Wu, G.Q. Chen, Energy and water nexus in power generation: the surprisingly high amount of industrial water use induced by solar power infrastructure in China, Appl. Energy 195 (2017) 125-136, https://doi.org/ 10.1016/j.apenergy.2017.03.029.

[61] E.A. Byers, J.W. Hall, J.M. Amezaga, Electricity generation and cooling water use: UK pathways to 2050, Global Environ. Change 25 (2014) 16-30, https:// doi.org/10.1016/j.gloenvcha.2014.01.005.

[62] T. Luo, D. Krishnan, S. Sen, Working Paper Parched Power: Water Demands, Risks, and Opportunities for India's Power Sector, 2018. Washington, DC.

[63] J. Cullis, N. Walker, F. Ahjum, D. Rodriguez, Modelling the Water-Energy Nexus: Should Regional Variability in Water Supply Impact on Decision Making for Future Energy Supply Options? Copernicus Publications, 2018, pp. 3-8. Proc. IAHS, 376.

[64] B.P. Walsh, S.N. Murray, D.T.J. O'Sullivan, The water energy nexus, an ISO50001 water case study and the need for a water value system, Water Resour Ind 10 (2015) 15-28, https://doi.org/10.1016/j.wri.2015.02.001.

[65] G.A. Thopil, A.A. Pouris, 20 year forecast of water usage in electricity generation for South Africa amidst water scarce conditions, Renew. Sustain. Energy Rev. 62 (2016) 1106-1121, https://doi.org/10.1016/ j.rser.2016.05.003.

[66] K. Hussey, J. Pittock, The energy-water nexus: managing the links between energy and water for a sustainable future, Ecol. Soc. (2012) 17, https:// doi.org/10.5751/ES-04641-170131.

[67] G. Simbolotti, Concentrating Solar Power Technology Brief E10, IRENA, 2013.

[68] A. Sastry, D.F. Duvenhage, J.E. Hoffmann, A parametric study of heliostat size for reductions in levelized cost of electricity, South Afr. Sol. Energy Conf. 2016 (2016) 1-8. Stellenbosch.

[69] G. Cáceres, M. Montané, S. Nasirov, R. O'Ryan, Review of thermal materials for CSP plants and LCOE evaluation for performance improvement using chilean strategic minerals: lithium salts and copper foams, Sustain (2016) 8, https://doi.org/10.3390/su8020106.

[70] C. Turchi, M. Mehos, C.K. Ho, G.J. Kolb, Current and Future Costs for Parabolic Trough and Power Tower Systems in the US Market Preprint, SolarPACES 2010, NREL, Perpignan, France, 2010, p. 11.

[71] M. Liu, N.H. Steven Tay, S. Bell, M. Belusko, R. Jacob, G. Will, et al., Review on concentrating solar power plants and new developments in high temperature thermal energy storage technologies, Renew. Sustain. Energy Rev. 53 (2016) 1411-1432, https://doi.org/10.1016/j.rser.2015.09.026.

[72] C. Parrado, A. Marzo, E. Fuentealba, A.G. Fernández, 2050 LCOE improvement using new molten salts for thermal energy storage in CSP plants, Renew. Sustain. Energy Rev. 57 (2016) 505-514, https://doi.org/10.1016/ j.rser.2015.12.148.

[73] IRENA, in: Renewable Energy Technologies Cost Analysis Series: Concentrating Solar Power, vol. 1, 2012. Abu Dhabi UAE.

[74] J. Hernandez-Moro, J.M. Martınez-Duart n, Analytical model for solar PV and CSP electricity costs: present LCOE values and their future evolution, Renew. Sustain. Energy Rev. 20 (2013) 119-132, https://doi.org/10.1016/ j.rser.2012.11.082.

[75] B.N. Green, C.D. Johnson, A. Adams, Writing narrative literature reviews for peer-reviewed journals: secrets of the trade, J Sport Chiropr Rehabil (2001) 5-19.

[76] R.A. Day, How to Write and Publish a Scientific Paper, fifth ed., The Oryx Press, Phoenix AZ, 1998.

[77] J. Baum, P.J. Vlok, Mapping primary constraints in physical asset management Strategy execution, using social network analysis, S. Afr. J. Ind. Eng. 24 (2013) 47-58.

[78] C. Labuschagne, A.C. Brent, Sustainable project life cycle management: the need to integrate life cycles in the manufacturing sector, Int. J. Proj. Manag. (2004), https://doi.org/10.1016/j.ijproman.2004.06.003.

[79] H.E. Cardwell, R.A. Cole, L.A. Cartwright, L.A. Martin, Integrated water resources management: definitions and conceptual musings, J Contemp Water Res Educ 135 (2009) 8-18, https://doi.org/10.1111/j.1936704X.2006.mp135001002.X.

[80] S. Makkonen, Decision Modelling Tools for Utilities in the Dregulated Energy Market, Helsinki University of Technology, 2005.

[81] Republic of South Africa Department of Energy, Integrated Resource Plan for Electricity 2010, 2010. Pretoria.

[82] Republic of South Africa Department of Energy, Integrated Energy Plan (IEP), 2016. Pretoria.

[83] Presidential Infrastructure Coordinating Commission, A Summary of the South African National Infrastructure Plan, 2012. Pretoria.

[84] Republic of South Africa Department of and Energy, Revised Strategic Plan: 2011/12 - 2015/16, 2012. Pretoria.

[85] NAMS, IPWEA, International Infrastructure Management Manual, fourth ed., New Zealand National Asset Management Steering Group, Wellington, NZ, 2011.

[86] D.F. Duvenhage, O.O. Craig, A.C. Brent, H.L.S. William, Future CSP in South 
Africa - a Review of Generation Mix Models, Their Assumptions, Methods, Results and Implications. SolarPACES 2017, AIP Publishing, Santiago Chile, 2017.

[87] S. Pfenninger, A. Hawkes, J. Keirstead, Energy systems modeling for twentyfirst century energy challenges, Renew. Sustain. Energy Rev. 33 (2014) 74-86, https://doi.org/10.1016/j.rser.2014.02.003.

[88] NETL, Estimating Freshwater Needs to Meet Future Thermoelectric Generation Requirements: 2010 Update, DOE/NETL-2011/1523, 2011. DOE/NETL400/2010/1339.

[89] D. Yates, J. Meldrum, F. Flores-Lopez, M. Davis, Integrated impacts of future electricity mix scenarios on select southeastern US water resources, Environ. Res. Lett. 8 (2013), https://doi.org/10.1088/1748-9326/8/3/035042.

[90] J. Macknick, S. Sattler, K. Averyt, S. Clemmer, J. Rogers, The water implications of generating electricity: water use across the United States based on different electricity pathways through 2050, Environ. Res. Lett. 7 (2012), https://doi.org/10.1088/1748-9326/7/4/045803.

[91] N. Nouri, Water Withdrawal and Consumption Reduction Analysis for Electrical Energy Generation System, University of Wisconsin-Milwaukee, 2015.

[92] Republic of South Africa Department of and Energy, Frequently Asked Questions -Integrated Energy Plan, IEP, Pretoria, 2016.

[93] Republic of South Africa Department of Minerals and Energy, White Paper on the Energy Policy of the Republic of South Africa, Department of Minerals and Energy, Pretoria, 1998.

[94] Republic of South Africa Department of Minerals and Energy, White Paper on Renewable Energy, Department of Minerals and Energy, Pretoria, 2003.

[95] IPP Projects, The South African Energy Independent Power Producers Procurement Programme (REIPPPP) - Lessons Learned, IPP Projects, Centurion South Africa, 2016.

[96] A. Eberhard, R. Naude, The South African renewable energy independent power producer procurement programme: a review and lessons learned, J. Energy South Afr. 27 (2016) 1-14.

[97] NERSA, in: Monitoring of Renewable Energy Performance of Power PLants, vol. 2017, NERSA, Pretoria, 2017.

[98] D.R. Walwyn, A.C. Brent, Renewable energy gathers steam in South Africa, Renew. Sustain. Energy Rev. 41 (2015) 390-401, https://doi.org/10.1016/ j.rser.2014.08.049.

[99] J.G. Wright, T. Bischof-Niemz, J. Calitz, C. Mushawana, R. van Heerden, M. Senatla, Formal Comments on the Integrated Resource Plan Update Assumptions, Base Case Results and Observations 2016, Council for Scientific and Industrial Research (CSIR), Pretoria, 2017.

[100] C.K. Ho, Software and codes for analysis of concentrating solar power technologies, 2008, pp. 1-35, https://doi.org/10.2172/946571. Sandia Natl Lab Rep SAND2008-8053.

[101] NREL, System Advisor Model 2017.9.5 User Manual, NREL, Palo Alto, CA, 2017.

[102] MinWaterCSP, CSP Plant Simulation Tool, 2018. http://www.minwatercsp. eu/technologies/csp-plant-simulation-tool/. (Accessed 3 June 2017).

[103] C. Wiiwer, W. Hube, P. Schossig, A. Wagner, C. Kettner, M. Mertins, et al., ColSim - A New Simulation Environment for Complex System Analysis and Controllers, Int. IBPSA Conf., Brazil: Fraunhofer ISE, 2001.

[104] About IWRM, Glob Water Partnersh, 2012. https://www.gwp.org/en/gwpSAS/ABOUT-GWP-SAS/WHY/About-IWRM/. (Accessed 22 January 2018).

[105] S. Pollard, D. Du Toit, Integrated water resource management in complex systems: how the catchment management strategies seek to achieve sustainability and equity in water resources in South Africa, WaterSA 34 (2008) $671-679$.

[106] K.W. Thornton, C. Laurin, J. Shortle, A. Fisher, J. Sobrinho, M. Stewart, A framework and guidelines for moving toward sustainable water resources management, Proc. Water Environ. Fed. WEFTEC 2006 (2006) 2762-2777.

[107] J. Denison, G. Mazibuko, MSB III Mid-term Review Implementation of Integrated Water Resource Management in Key Priority Areas, DWAF, Pretoria, 2010.

[108] F. Zare, S. Elsawah, T. Iwanaga, A.J. Jakeman, S.A. Pierce, Integrated water assessment and modelling: a bibliometric analysis of trends in the water resource sector, J. Hydrol. 552 (2017) 765-778.

[109] United Nations, Earth Summit'92. The UN Conference on Environment and Development, United Nations Division for Sustainable Development, Rio de Janerio, 1992.

[110] Savenije HHG, Hoekstra AY. Water Resources Management. vol. vol. I. UNESCO-EOLSS; n.d.

[111] K.W. Thornton, C. Laurin, D. Catanzaro, J. Shortle, A. Fisher, J. Sobrinho, et al., Moving toward Sustainable Water Resources Management: a Framework and Guidelines for Implementation. Synthesis Report, Water Environment Research Foundation, Alexandria, VA, 2006.

[112] K. Thornton, C. Laurin, D. Catanzaro, J. Shortle, A. Fisher, J. Sobrinho, et al., Moving toward Sustainable Water Resources Management: a Framework and Guidelines for Implementation, Technical Report 00-WSM-6b, Water Environment Research Foundation, Alexandria, VA, 2006.

[113] Sustainable Water Resources Management Volume 1: Executive Summary. vol. vol. 5. Palo Alto, CA and Alexandria, VA: EPRI and WERF; 2010.

[114] W.V. Pitman, A Mathematical Model for Generating Monthly River Flows from Meteorological Data in South Africa. HRU Report No. 2/73, Hydrological Research Unit, University of the Witwatersrand, Johannesburg, 1973.

[115] World Business Council for Sustainable Development, Global Water Tool, 2015, pp. 1-9. Version 2015 1.3.
[116] N. Hanasaki, S. Kanae, T. Oki, K. Masuda, K. Motoya, N. Shirakawa, et al., An integrated model for the assessment of global water resources - Part 1: model description and input meteorological forcing, Hydrol. Earth Syst. Sci. 12 (2008) 1007-1025, https://doi.org/10.5194/hess-12-1027-2008.

[117] D. Juizo, R. Liden, Modeling for transboundary water resources planning and allocation: the case of Southern Africa, Hydrol. Earth Syst. Sci. 14 (2010) 2343-2354, https://doi.org/10.5194/hess-14-2343-2010.

[118] O.I. Nkwonta, B. Dzwairo, F.A.O. Otieno, J.A. Adeyemo, A review on water resources yield model, S. Afr. J. Chem. Eng. 23 (2017) 107-115, https:// doi.org/10.1016/j.sajce.2017.04.002.

[119] A. Bailey, WRSM2000/Pitman Water Resources Simulation Model for Windows: Theory, HaskoningDHV Ltd, WRC and DWS, Pretoria, 2015.

[120] N.J. Van Wyk, J.A. Van Rooyen, P.G. Van Rooyen, F.G.B. De Jager, Proposed Modelling Approach and Procedures for Water Availability Assessment Studies, 2005, pp. 1-10.

[121] R. Mckenzie, C. Seago, Current Analytical Methods and Technical Capacity of the Four Orange Basin States, ORASECOM, Pretoria, 2007.

[122] A. Bailey, W. Pitman, Water Resources of South Africa 2012 Study (WR2012) Executive Summary, HaskoningDHV Ltd, WRC and DWS, Pretoria, 2015.

[123] W.V. Pitman, J.P. Kakebeeke, A.K. Bailey, WRSM/Piman Water Resources Simulation Model: Users Manual, HaskoningDHV Ltd, WRC and DWS, Pretoria, 2015.

[124] D. Sparks, A. Dane, Renewable energy choices and their water requirements in South Africa, J. Energy South Afr. 25 (2014) 80-92.

[125] H.M. Cekirge, A. Elhassan, A comparison of solar power systems ( CSP ): solar tower ( ST ) systems versus parabolic trough ( PT ) systems 2 . Comparison of solar tower ( ST ) and, Am. J. Energy Eng. 3 (2015) 29-36, https://doi.org/ 10.11648/j.ajee.20150303.11.

[126] M.J. Rutberg, H.J. Herzog, A.F. Ghoniem, A. Delgado, A System-Level Generic Model of Water Use at Power Plants and its Application to Regional Water Use Estimation. IMECE2011, ASME, Denver Colorado, 2011, pp. 1-11.

[127] A. Kohli, K. Frenken, Cooling Water for Energy Generation and its Impact on National-level Water Statistics, 2011. Rome, Italy.

[128] M.J. Wagner, C.F. Kutscher, Assessing the Impact of Heat Rejection Technology on CSP Plant Revenue. SolarPACES 2010, NREL, Perpignan, France, 2010, pp. $1-9$.

[129] R. Putman, D. Jaresch, The Cleaning of Air Cooled Condensers to Improve Performance, ASME, Phoenix, AZ, 2002. Int. Jt. Power Gener. Conf.

[130] J. Macknick, R. Newmark, G. Heath, K.C. Hallett, Operational water consumption and withdrawal factors for electricity generating technologies: a review of existing literature, Environ. Res. Lett. 7 (2012), https://doi.org/ 10.1088/1748-9326/7/4/045802.

[131] V. Fthenakis, H.C. Kim, Life-cycle uses of water in U.S. electricity generation Renew. Sustain. Energy Rev. 14 (2010) 2039-2048, https://doi.org/10.1016/ j.rser.2010.03.008.

[132] J. Macknick, J. Meldrum, S. Nettles-Anderson, G. Heath, A. Miara, Life cycle water use for photovoltaic electricity generation: a review and harmonization of literature estimates, Environ. Res. Lett. 8 (2013) 1-18, https://doi.org/ 10.1109/PVSC.2014.6925190.

[133] N. Bracken, J. Macknick, A. Tovar-hastings, P. Komor, M. Gerritsen, S. Mehta Concentrating Solar Power and Water Issues in the U.S. Southwest, Joint Institute for Strategic Energy Analysis, Golden, Colorado, 2015.

[134] G.E. Cohen, D.W. Kearney, G.J. Kolb, Final Report on the Operation and Maintenance Improvement Program for Concentrating Solar Power Plants. SAND99-1290, Sandia National Laboratories, Albuquerque, New Mexico, 1999.

[135] A. Raza, A.R. Higgo, A. Alobaidli, T. Zhang, Water recovery in a concentrated solar power plant, AIP Conf Proc (2016) 1734, https://doi.org/10.1063/ 1.4949255.

[136] MinWaterCSP, MinWaterCSP, 2018. August 6, 2016, http://www. minwatercsp.eu/.

[137] L. Heller, Literature Review on Heat Transfer Fluids and Thermal Energy Storage Systems in CSP Plants-sterg Report, RSA, Stellenbosch, 2013.

[138] International Association of Engineering Insurers, IMIA Working Group Paper WG 84 (14) - Solar Thermal Power Plant, Cannes, France, 2014.

[139] N. Middleton, D.S.G. Thomas, United Nations Environment Programme World Atlas of Desertification, Arnold, 1997.

[140] F. Gassert, M. Landis, M. Luck, P. Reig, T. Shiao, Aqueduct Global Maps 2.1: Constructing Decision-relevant Global Water Risk Indicators, 2014. Washington, DC.

[141] T. Luo, Droughts and Blackouts: How Water Shortages Cost India Enough Energy to Power Sri Lanka, WRI, 2017. http://www.wri.org/blog/2017/07/ droughts-and-blackouts-how-water-shortages-cost-india-enough-energypower-sri-lanka. (Accessed 2 February 2018).

[142] D. Das, NTPC plant Shutdown Hits Power Supply in 5 States, 2018. http:// www.thehindubusinessline.com/companies/ntpc-plant-shutdown-hitspower-supply-in-5-states/article8352253.ece. (Accessed 2 March 2018).

[143] J. McCall, J. Macknick, D. Hillman, Water-related Power Plant Curtailments: an Overview of Incidents and Contributing Factors, NREL, Golden, Colorado, 2016, https://doi.org/10.2172/1338176. NREL/TP-6A20-67084.

[144] M. Van Vliet, J.R. Yearsley, F. Ludwig, S. Vögele, D. Lettenmaier, P. Kabat Vulnerability of US and European electricity supply to climate change, Nat. Clim. Change 2 (2012) 676-681.

[145] NETL, Impact of Drought on U.S. Steam Electric Power Plant Cooling Water Intakes and Related Water Resource Management Issues, National Energy 
Technology Laboratory, 2009. DOE/NETL-2009/1364.

[146] C. Silinga, P. Gauché, W Van Niekerk, CSP scenarios in South Africa: benefits of CSP and the lessons learned, SolarPACES 070031 (2015) 0-8, https:/ doi.org/10.1063/1.4949178.

[147] N. Shand, Guidelines for Water Supply Systems Operation and Management Plans during Normal and Drought Conditions (RSA C000/00/2305, DEPARTMENT OF WATER AFFAIRS AND FORESTRY, Pretoria, 2006.

[148] G.T. Klise, V.C. Tidwell, M.D. Reno, B.D. Moreland, M. Katie, J. Macknick, Water Use and Supply Concerns for Utility-scale Solar Projects in the Southwestern United States. SAND2013-5238, Sandia National Laboratories, Albuquerque, New Mexico, 2013.

[149] A. Eberhard, R. Naude, The South African Renewable Energy Ipp Procurement Programme Review, Lessons Learned \& Proposals to Reduce Transaction Costs, University of Cape Town Graduate Business School, Cape Town, 2017.

[150] Department of Water Affairs and Forestry, External Guideline: Generic Water USe Authorisation Application Process, Department of Water Affairs and Forestry, Pretoria, 2007.

[151] National Water Act, Department of Water Affairs and Forestry, 1998, p. 94.

[152] A. Pouris, G.A. Thiopil, Long Term Forecasts of Water Usage for Electricity Generation: South Africa 2030. Report No. 2383/1/14. Pre, Water Research
Commission, 2015.

[153] South African Department of Water and Sanitation, Department of Water and Sanitation ( DWS ) Guidance Note Regarding Water Availability and Water Use Licensing for the Coal Baseload Independent Power Producer ( IPP ) Procurement Programme, 2015. Pretoria.

[154] D.F. Duvenhage, M. Kleingeld, A.J. Schutte, Integration of DSM interventions into bulk water supply strategies, IEEE, Cape, 2016, pp. 2-8, 2016 Int. Conf. Ind. Commer. Use Energy.

[155] T.A. DeNooyer, J.M. Peschel, Z. Zhang, A.S. Stillwell, Integrating water resources and power generation: the energy-water nexus in Illinois, Appl.

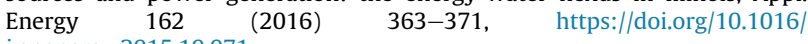
j.apenergy.2015.10.071.

[156] A.S. Stillwell, Water Impacts on Thermoelectric Power Generation, University of Texas at Austin, 2013.

[157] GAO, Water in the Energy Sector Reducing Freshwater Use in Hydraulic Fracturing and Thermoelectric Power Plant Cooling, GAO-15-545, United States Government Accountability Offi, Washington, DC, 2015.

[158] C.A. Scott, M.J. Pasqualetti, Energy and water resources scarcity: critical infrastructure for growth and economic development in Arizona and Sonora, Nat. Resour. J. 50 (2010) 645-682. http://lawschool.unm.edu/NRJ/. 